\title{
Ammonia-oxidizer communities in an agricultural soil treated with contrasting nitrogen sources
}

\author{
Mussie Y. Habteselassie ${ }^{1}, \mathrm{Li}_{\mathrm{X}} \mathrm{u}^{2}$ and Jeanette M. Norton ${ }^{3}$ * \\ 1 Department of Crop and Soil Sciences, The University of Georgia Griffin Campus, Griffin, GA, USA \\ ${ }^{2}$ College of Resources and Environmental Sciences, Nanjing Agriculture University, Nanjing, China \\ ${ }^{3}$ Department of Plant, Soils and Climate, Utah State University, Logan, UT, USA
}

\section{Edited by:}

Paul Bodelier, Netherlands Institute of Ecology (NIOO-KNAW), Netherlands

\section{Reviewed by:}

Graeme W. Nicol, University of Aberdeen, UK

Peter Bottomley, Oregon State

University, USA

\section{*Correspondence:}

Jeanette M. Norton, Department of Plant, Soils and Climate, Utah State University, 4820 Old Main Hill, Logan, UT 84322, USA

e-mail: jeanette.norton@usu.edu
The community of ammonia-oxidizing prokaryotes was examined in an agricultural soil treated for six seasons with contrasting nitrogen (N) sources. Molecular tools based on the genes encoding ammonia monooxygenase were used to characterize the ammonia oxidizer (AO) communities and their abundance. Soil DNA was extracted from soils sampled from silage corn plots that received no additional $\mathrm{N}$ (control), dairy waste compost, liquid dairy waste (LW), and ammonium sulfate (AS) treatments at approximately 100 and $200 \mathrm{~kg}$ available $N$ ha $^{-1}$ over 6 years. The $\mathrm{N}$ treatment affected the quantity of $\mathrm{AO}$ based on estimates of amoA by real-time PCR. Ammonia oxidizing bacteria (AOB) were higher in soils from the AS200, AS100, and LW200 treatments $\left(2.5 \times 10^{7}, 2.5 \times 10^{7}\right.$, and $2.1 \times 10^{7}$ copies $\mathrm{g}^{-1}$ soil, respectively) than in the control $\left(8.1 \times 10^{6}\right.$ copies $^{-1}$ soil) while the abundance of amoA encoding archaea [ammonia oxidizing archaea (AOA)] was not significantly affected by treatment $\left(3.8 \times 10^{7}\right.$ copies $\mathrm{g}^{-1}$ soil, average). The ratio of $\mathrm{AOA} / \mathrm{AOB}$ was higher in the control and compost treated soils, both treatments have the majority of their ammonium supplied through mineralization of organic nitrogen. Clone libraries of partial amoA sequences indicated $A O B$ related to Nitrosospira multiformis and AOA related to uncultured Nitrososphaera similar to those described by soil fosmid $54 d 9$ were prevalent. Profiles of the amoC-amoA intergenic region indicated that both Nitrosospira- and Nitrosomonas-type AOB were present in all soils examined. In contrast to the intergenic amoC-amoA profile results, Nitrosomonas-like clones were recovered only in the LW200 treated soil-DNA. The impact of 6 years of contrasting nitrogen sources applications caused changes in $\mathrm{AO}$ abundance while the community composition remained relatively stable for both $\mathrm{AOB}$ and $\mathrm{AOA}$.

Keywords: nitrification, ammonia monooxygenase, nitrogen fertilizers, agricultural soils, manure, compost ammonia oxidizing archaea, ammonia oxidizing bacteria

\section{INTRODUCTION}

In soil environments ammonia oxidizing bacteria $(\mathrm{AOB})$ and ammonia oxidizing archaea $(\mathrm{AOA})$ mediate the first, rate-liming step of autotrophic nitrification, which is considered to be a key control point in the nitrogen cycle resulting in increased $\mathrm{N}$ mobility and loss of oxidized $\mathrm{N}$ forms through leaching and denitrification (Norton, 2008; Schleper, 2010). Several studies have indicated that $\mathrm{AOB}$ and $\mathrm{AOA}$ co-exist and play important roles in soils but questions remain concerning their relative importance in agricultural soil environments (Leininger et al., 2006; Jia and Conrad, 2009; Di et al., 2010; Wessen et al., 2010). Ammonia oxidizers $\mathrm{AO})$ are generally slow growing, difficult to isolate and have therefore have been primarily investigated using molecular techniques based on amplification of genes encoding either the $16 \mathrm{~S}$ ribosomal RNA or ammonia monooxygenase (amo) (Rotthauwe et al., 1997; Purkhold et al., 2000; Kowalchuk and Stephen, 2001; Prosser and Embley, 2002; Junier et al., 2010)

Assessment of the impacts of treatment or management systems on nitrification rates requires consideration of microbial abundance in addition to microbial diversity due to differences in microbial response at low and high cell concentrations (Webster et al., 2005). Molecular investigations of $\mathrm{AO}$ in the environment have mainly focused on methods which can be summarized into three groups: (1) PCR amplification of a target gene followed by either clone assisted or direct sequence analysis, (2) hybridization of whole cell or PCR amplified DNA fragments with specific oligonucleotides probes, and (3) analysis of PCR products with profiling techniques such as denaturing gradient gel electrophoresis (DGGE) or terminal fragment length polymorphism. Norton et al. (2002) reported the possibility of using the variable length intergenic region between $a m o C$ and $a m o A$ (genes encoding two of the AMO subunits) to profile AOB in environmental samples without cloning or sequencing. This profiling method has advantages for rapid assessment within related communities. The current experimental system has several aspects that include: (1) original soil environment relatively homogeneous and wellcharacterized, (2) multiple year treatments with same crop and soil amendments in a replicated field experiment, and coordinated microbial community and functional rate studies on the same experimental system. We interpret our observations to examine 
the extent of functional redundancy versus niche separation for the two major groups of ammonia oxidizing prokaryotes under contrasting sources of available $\mathrm{N}$.

\section{MATERIALS AND METHODS EXPERIMENTAL FIELD PLOTS}

The experimental design, soil, treatments and nitrogen dynamics of this experiment have been previously described (Shi et al., 2004; Habteselassie et al., 2006a,b). The soil is an irrigated, very strongly calcareous Millville silt loam (Coarse-silty, carbonatic, mesic Typic Haploxeroll) with $\mathrm{pH}_{1: 1}$ of 8.2 and CEC of $14 \mathrm{cmolc}^{-1}$. The experimental design is a complete randomized block with four replications of seven nitrogen treatments. Treatments are control (no N fertilization), low level dairy waste compost (DC100), high level DC (DC200), low level liquid dairy waste (LW100), high level LW (LW200), and ammonium sulfate (AS) at 100 and $200 \mathrm{~kg}$ available $\mathrm{N} \mathrm{ha}^{-1}$ (AS100 and AS200) annually from 1997 to 2003. The low and high levels of waste treatments were applied to provide approximately 100 and $200 \mathrm{~kg}$ available $\mathrm{N} \mathrm{ha}^{-1}$ after considering contributions from soil organic matter and previous year applications (Habteselassie et al., 2006a,b). Treatments were applied in early May and incorporated into approximately the top $10 \mathrm{~cm}$. The plots were planted each year with silage corn. Two soil cores $(3 \times 15 \mathrm{~cm})$ were collected from each replicate plot in August 2002 and 2003 and frozen $\left(-20^{\circ} \mathrm{C}\right)$ until used.

\section{BACTERIAL STRAINS AND DNA EXTRACTION}

Genomic DNA of strains of Nitrosospira sp. NpAV, Nitrosospira multiformis 24C, Nitrosospira sp. 39-19, Nitrosospira briensis C128, Nitrosospira tenuis NV-12, Nitrosolobus multiformis 25196, Nitrosomonas europeae 19178, Nitrosomonas eutropha C-91, and Nitrosomonas cryotolerans 49181 were used as references for profiling AOB based on the variable size amo intergenic region and for primer development (Norton et al., 2002). DNA from soil samples was extracted as described in Zhou et al. (1996) and purified using gel electrophoresis or using a commercial kit (Power Soil MoBio, Carlsbad, CA, USA) before further analysis or PCR.

\section{OUANTITATIVE ANALYSIS OF AO WITH REAL-TIME PCR}

The copy number of bacterial and archaeal amoA in DNA extracted from all soil samples was determined similarly to the approach of Leininger (Leininger et al., 2006). The real-time PCR was carried out in a iCycler iQ5 instrument (Bio-Rad laboratories, USA) with the amoA189F/amoA2R' primer set (Okano et al., 2004) for $\mathrm{AOB}$ and the $a m o 19 \mathrm{~F}$ and amo643R primers for AOA (Leininger et al., 2006) using the $\mathrm{iQ}^{\mathrm{TM}} 2 \times \mathrm{SYBR}^{\circledR}$ green super mix [100 mM $\mathrm{KCl}, 40 \mathrm{mM}$ Tris- $\mathrm{HCl}, \mathrm{pH} 8.4,0.4 \mathrm{mM}$ of each dNTP, iTaq DNA polymerase, $50 \mathrm{U} / \mathrm{mL}, 6 \mathrm{mM} \mathrm{MgCl}_{2}$, SYBR Green I, $20 \mathrm{nM}$ fluorescein, and stabilizers (Bio-Rad laboratories, Hercules, CA, USA)]. The standard curve for quantification of amoA copy number used plasmids containing cloned amoA products from genomic DNA of Nitrosospira multiformis ATCC 25196 or from environmental DNA. Improved quantification was obtained after diluting the soil DNA extracts by $10 \times$ before quantification. Each $25 \mu \mathrm{L}$ reaction contained $12.5 \mu \mathrm{L} 2 \times \mathrm{SYBR}^{\circledR}$ green super mix, $1.0 \mu \mathrm{L}$ of extracted DNA, $1.25 \mu \mathrm{L}$ of both forward and reverse primers
(500 $\mathrm{nM}$ reaction concentration), $0.5 \mu \mathrm{L}$ bovine serum albu$\min \left(400 \mathrm{ng} \mu \mathrm{L}^{-1}\right.$ reaction concentration) and $8.5 \mu \mathrm{L}$ of water. The amplification used the following protocol: an initial denaturation step of $95^{\circ} \mathrm{C}$ for $10 \mathrm{~min}, 40$ cycles of $95^{\circ} \mathrm{C}$ for $45 \mathrm{~s}$, $60.1^{\circ} \mathrm{C}$ for $1 \mathrm{~min}$, and $72^{\circ} \mathrm{C}$ for $45 \mathrm{~s}$ and a final extension step of $72^{\circ} \mathrm{C}$ for $10 \mathrm{~min}$. Fluorescence intensity was measured during the $72^{\circ} \mathrm{C}$ step of each cycle, and a melt curve was performed after the final extension step to confirm the specificity of the amplified DNA. All standards and samples were processed in triplicate. PCR reactions showed high efficiencies and no inhibition was detected. The standard curve for quantification of the copies of amoA from soils was log-linear with $R^{2}$ values 0.99 or greater.

\section{PROFILING AOB BASED ON THE VARIABLE SIZE amoC-amoA INTERGENIC REGION}

Primers that target the intergenic region between amoC and amoA were designed and evaluated with the help of the Amplify (Engels, 1993) and Windows 32 Primerselect 5.05 (DNASTAR, Inc., Madison, WI, USA) programs from several amo sequences that were obtained from our sequence library and GenBank. All the primers used in this study are summarized in Table 1 and synthesized commercially (Genemed Synthesis Inc., or Operon Technologies). Soil DNA extracts were PCR amplified with amoC311F/amoA302R and amoC305F/amoA302R primer sets employing Taq polymerase (Promega, Madison, WI, USA). No visible amplification products were obtained. Semi-nesting of the PCR products with amoC311F/amoA310R, amoC305F/amoA310R, and amoC305F/amoA304R gave visible and variable size bands. The PCR conditions were $4 \mathrm{~min}$ at $94^{\circ} \mathrm{C}$ followed by 42 (soil samples) or 30 (genomic DNA) cycles at $94^{\circ} \mathrm{C}$ for $1 \mathrm{~min}, 52^{\circ} \mathrm{C}$ for $1 \mathrm{~min}, 72^{\circ} \mathrm{C}$ for $4 \mathrm{~min}$ with a final extension step of $10 \mathrm{~min}$ at $72^{\circ} \mathrm{C}$.

The annealing temperature for the genomic DNA and the seminesting step was raised to $57^{\circ} \mathrm{C}$ to avoid non-specific amplification. The intergenic amplicons were run in a $3 \%$ high-resolution agarose gel and visualized in UV light after staining with ethidium bromide. The bands were analyzed using the RFLPscan program (Scanalytics/CSPI, Billerica, MA, USA). The bands were further analyzed with $a m o C$ and $a m o A$ specific probes to verify their similarity to known amo sequences (data not shown). The intergenic banding profiles were analyzed as a matrix of shared bands/ total bands for all the blocks and the matrices clustered by average linkage methods using SAS (version 9.3).

\section{CLONE LIBRARIES OF amOA FROM SOIL DNA}

Soil DNA extracts from AS200, DC200 and LW200 plots were amplified with Taq bead hot start polymerase (Promega, Madison, WI) and primer sets targeting amoA to obtain fragments of $a m o A$ for developing clone libraries. The PCR products were run in $0.8 \%$ agarose gel. Bands of the right size were cut out and purified. The purified PCR products were ligated into pCR II plasmids and One Shot competent Escherichia coli cells were transformed according to the manufacturer's instructions (TA Cloning Systems, Invitrogen, San Diego, CA, USA). The transformation products were plated on LB agar containing kanamycin (50 $\mathrm{mg} \mathrm{L}^{-1}$ ). For soils from each treatment (AS200, DC200, and 
Table 1 | Primers used in this study for a real time PCR assay of amoA, amplification of the intergenic region between amoC and amoA, and development of amoA clone libraries from soil DNA.

\begin{tabular}{|c|c|c|c|c|c|}
\hline Name & Sequence $\left(5^{\prime}-3^{\prime}\right)$ & Position $^{a}$ & Conc. (nM) & Reference & Description \\
\hline AmoA189F & GGHGACTGGGAYTTCTGG & $1130-1147$ & 500 & Holmes etal. (1995) & $\begin{array}{l}\text { Real time PCR and clone library for } \\
\text { Bacteria }\end{array}$ \\
\hline$A m o A 2 R^{\prime}$ & CCTCKGSAAAGCCTTCTTC & $1781-1799$ & 500 & Okano et al. (2004) & \\
\hline Amo19F & ATGGTCTGGCTWAGACG & & 500 & Leininger et al. (2006) & $\begin{array}{l}\text { Real time PCR and clone library for } \\
\text { Archaea }\end{array}$ \\
\hline AmoA302R & TTTGATCCСCTCTGGAAAGCCTTCTTC & $1781-1808$ & 500 & Norton et al. (2002) & $\begin{array}{l}\text { AOB profile based on variable size } \\
\text { amoC-amoA intergenic region }\end{array}$ \\
\hline AmoC305F & GTGGTTTGGAACRGNCARAGCAAA & $763-786$ & 500 & Norton et al. (2002) & \\
\hline AmoA310R & TACCGCTTCCGGCGGCATTTTCGCC & $1015-1039$ & 500 & This study & \\
\hline
\end{tabular}

a Positions in N. europaea amoCAB2 sequence (McTavish etal., 1993; Norton etal., 2002; Chain etal., 2003).

LW200 for AOB, all treatments for AOA), more than 40 clones were randomly selected and grown overnight in terrific broth. The plasmids were purified (MO BIO Inc., Carlsbad, CA) and analyzed for the presence of inserts with restriction digestion using EcoRI before they were sequenced with M13R primer and DNA polymerase for dideoxy dye-primer cyclo-sequencing (ABI 373A, USU Center for Integrated Biosystems). Nucleotide sequences were cleaned of vector and primer contamination and checked for frame shift errors using Sequencher software (Gene Codes, Madison, WI, USA) and investigated for sequence identity and similarity using the NCBI Blast (Altschul et al., 1997) and MegAlign (DNASTAR, Inc., Madison, WI, USA) programs. Multiple alignments of sequences were done with the ClustalW software. All the sequences were first aligned and the subsection of the alignment excluding primers was used for further analysis using the ARB programs (Ludwig etal., 2004). AOA amoA sequences were trimmed to $570 \mathrm{bp}$ and aligned to an existing high-quality amo $A$ database (http://www.ncbi.nlm.nih.gov/pmc/articles/PMC3328746/bin/em i0014-0525-SD1.arb) and the 97\% identity phylogenetic tree of Pester et al. (Pester et al., 2012). All AOA sequences were above the $85 \%$ identity level with existing sequences in the database. AOB amoA sequences were aligned with ClustalW and trimmed to $534 \mathrm{bp}$ and then analyzed with the interactive parsimony tool within the ARB package (Ludwig et al., 2004). Reference sequences were retrieved from GenBank or from (Norton et al., 2002). The amoA sequences from this study are available as accessions KF541098-KF541236 in GenBank (Benson et al., 2008).

\section{STATISTICAL ANALYSIS}

Results were summarized with descriptive statistics (e.g., mean, standard error). The amoA copy numbers were subject to ANOVA analysis to test the statistical significance of the different $\mathrm{N}$ sources on bacterial and archaeal amoA abundance. Tukey's Studentized Range Test was used for means separation. The data was log transformed after the necessary test for normality and homogeneity of variance. ANOVA analysis was also done to test the significance of difference between $\mathrm{AOB}$ and $\mathrm{AOA}$ amoA copy numbers for each
$\mathrm{N}$ source or treatment. All statistical analyzes were done in SAS (2002-2003, SAS Institute, Inc., North Carolina) at significance level of $\alpha=0.05$.

\section{RESULTS AND DISCUSSION QUANTIFICATION OF AOB AND AOA WITH REAL TIME PCR}

The copy number of amoA genes from AOB and AOA in soils that received different treatments is shown in Figure 1. For AOB amo $A$ copies ranged from $8 \times 10^{6}$ to $3 \times 10^{7} \mathrm{~g}^{-1}$ soil equivalent to approximately $10^{6}$ to $10^{7}$ cells $\mathrm{g}^{-1}$ soil assuming 2-3 copies of $a m o A$ per cell (Norton et al., 2002). These numbers are comparable or slightly higher than the AOB population sizes reported in agricultural soils using competitive and real-time PCR techniques by targeting amoA and $16 \mathrm{~S}$ rDNA

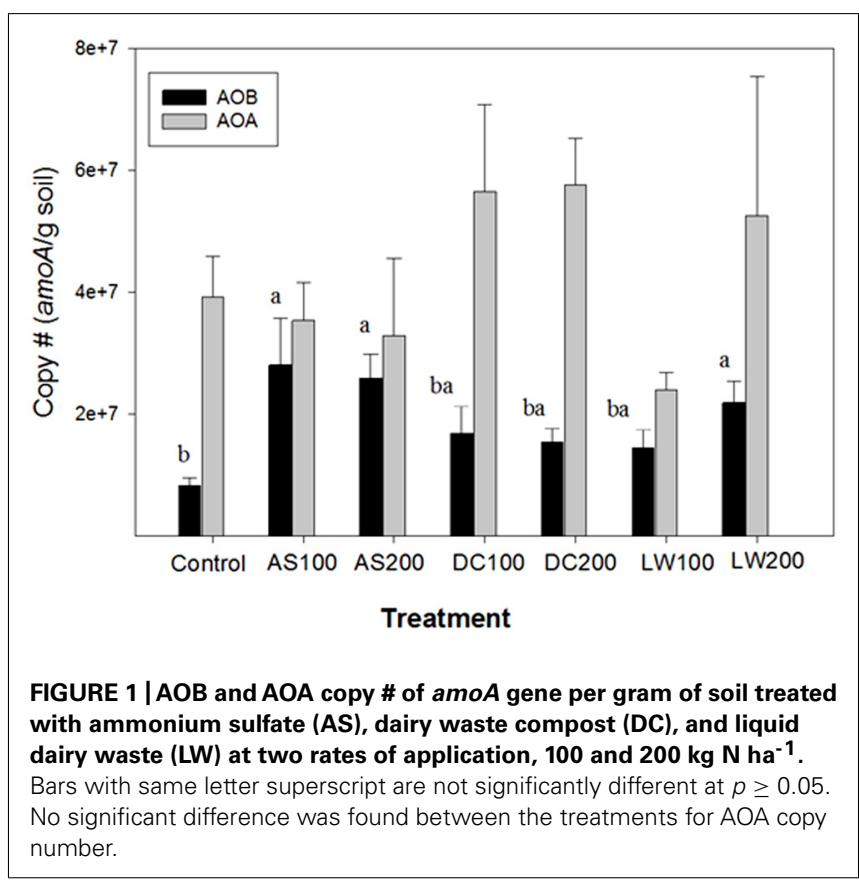


(Phillips et al., 2000b; Mendum and Hirsch, 2002; Okano et al., 2004; Jia and Conrad, 2009; Gubry-Rangin et al., 2010).

In our study, higher $\mathrm{AOB}$ populations were found in soils from the AS100, AS200 and LW200 treatments compared to the control soil. The DC treatment did not result in a significantly higher $\mathrm{AOB}$ population size than the control. This is consistent with a study by Innerebner et al. (2006) in which AOB population size in the control soil was not significantly different from the soil that received cattle manure compost, a kind of compost similar to ours, for more than 10 years at $175 \mathrm{~kg} \mathrm{~N} \mathrm{ha}^{-1}$ annually. The AS and LW treatments in our study were similar in that most of the $\mathrm{N}$ was found in a more readily available (inorganic) form as opposed to the control or DC treatments (Habteselassie et al., 2006a). The spring fertilizer pulse of available ammonium will most likely stimulate activity and possibly growth of $\mathrm{AOB}$ over a short period of time (Shi et al., 2004). In these soils nitrification rates are rapidly increased by ammonium additions when compared to gross nitrification rates suggesting ammonium limitation of ammonia oxidation (Habteselassie et al., 2006b; Koper et al., 2010). In a soil microcosm study, Okano et al. (2004) reported 8 and 11 fold increases in $\mathrm{AOB}$ population size one week after AS applications at 80 and $400 \mathrm{~kg} \mathrm{~N} \mathrm{ha}^{-1}$ rates, respectively. The potentially mineralizable $\mathrm{N}$ pool size is, however, higher in DC than AS or LW treated soils (Habteselassie et al., 2006b). This pool releases ammonium slowly over a longer period of time, which will most likely lead to a more sustained and consistent $\mathrm{AO}$ population size throughout the season in the DC treated plots as opposed to AS or LW treated plots. Our study, however, did not measure seasonal changes in AO population size in the differently treated plots. Phillips et al. (2000b) and Mendum and Hirsch (2002) had similarly reported increased $\mathrm{AOB}$ population size as a result of ammonium nitrate and AS fertilization, respectively. The magnitude of the increase in AOB population size was dependent on the time between fertilization and measurement. The above findings are also supported by recent studies that reported significant increases in AOB abundance as a result of fertilization with mineral sources of $\mathrm{N}$ under both field and soil microcosm set-ups (Verhamme et al., 2011; Taylor et al., 2012).

Based on 2 to 5 fold higher potential and gross nitrification rates measurements in the DC200 versus the AS200 treated soils (Habteselassie et al., 2006a,b), it was expected that DC200 treated soil would have larger, if not similar AO population size in comparison to the AS200 treated soils. Contrary to our expectation there was no significant difference for either the AOA nor the AOB populations between the DC treated soils and the other treatments. One reason for this could be that the organic matter content of soils that received the DC200 treatment increased twofold over 6 years (Habteselassie et al., 2006a). These rapid increases in organic matter creates hot spots of mineralization and nitrification due to uneven distribution of waste (Korsaeth et al., 2001) suggesting increased heterogeneity in the DC treated soils.

During the extent of this field study the role of archaeal prokaryotes containing putative amoA genes in soils became known (Leininger et al., 2006). In our study using archived samples, we were able to quantify the amoA gene copies based on primers targeting archaeal AO (Leininger et al., 2006). The archaeal amoA gene copies were similar or higher than those found for $\mathrm{AOB}$ $a m o A$ genes with an average value of $3.8 \times 10^{7}$ per gram soil, with no significant differences between soil treatments (Figure 1). The ratio of archaeal to bacterial amoA gene copies is shown in Figure 2. The ratio of AOA/AOB was higher in the control and compost treated soils versus the other treatments. The supply of ammonium via mineralization is higher in the compost treated soils (four year average DC200 treatment is $5.7 \mathrm{mg} \mathrm{N}$ $\left.\mathrm{kg}^{-1} \mathrm{~d}^{-1}\right)$ versus the control $\left(1.4 \mathrm{mg} \mathrm{N} \mathrm{kg}^{-1} \mathrm{~d}^{-1}\right)$ or the AS200 $\left(1.3 \mathrm{mg} \mathrm{N} \mathrm{kg}^{-1} \mathrm{~d}^{-1}\right.$ ) treated soils. However, the DC and Control soils have in common that the majority of their ammonium is supplied through mineralization of organic nitrogen rather than directly through ammonium additions in fertilizers (AS) or LW (Habteselassie et al., 2006a,b). Our findings are consistent with other studies that show AOB are favored by inputs of ammonium. In a wetland soil, AOB abundance was higher in soils with ammonium additions from a septic tank leak compared to unpolluted soils (Hofferle et al., 2010). In fallowed or pasture soils where organic matter was higher than matched cropped fertilized soils, AOA abundance was several fold higher than AOB abundance (Taylor et al., 2010; Zeglin et al., 2011). Under high ammonium concentration, as in situations where ammonium is supplied in a readily available mineral form, $\mathrm{AOB}$ abundance was either comparable or higher than the corresponding AOA abundance (Di et al., 2010; Verhamme et al., 2011; Taylor et al., 2012). These studies, along with ours, clearly indicate differential growth response by $\mathrm{AOA}$ and $\mathrm{AOB}$ to different forms and concentrations of nitrogen sources.

Functional differences between AOB and AOA have also been reported under different soil treatments. Using stable isotope probing technique, Xia et al. (2011) reported the functional dominance of AOB in agricultural soil that received AS $\left(100 \mu \mathrm{g} \mathrm{N} \mathrm{g}^{-1}\right.$ soil per week) as opposed to AOA. AOA contribution to nitrification was calculated to be a maximum of $23.4 \%$, the rest coming from $\mathrm{AOB}$. AOB were also functionally dominant, as assessed by

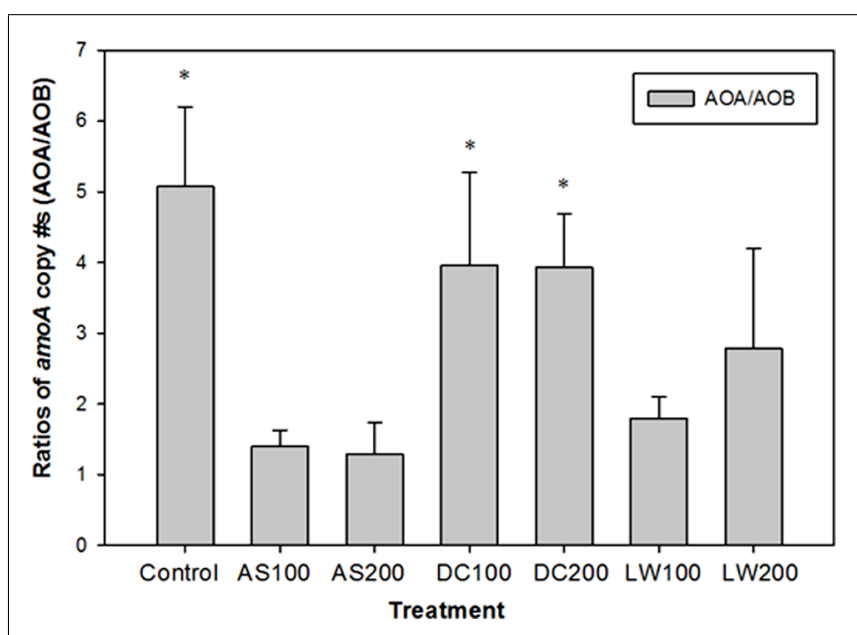

FIGURE 2 | Ratios of amoA copy \# per gram of soil of AOA to AOB. Soil treatments as in Figure 1. *Bars with asterisk indicate that the copy \# of amoA of AOA is significantly higher than the copy \# of amoA of AOB for that treatment at $p \leq 0.05$. 
measuring nitrification rate and amo $A$ gene transcription activity, in grassland soils that received very high urea concentration to simulate urine patches (Di et al., 2010). AOA were, on the other hand, the more dominant players in nitrification in an organic soil based on acetylene inhibition technique (Offre et al., 2009). A study by Taylor et al. (2010) showed that in recently $\mathrm{N}$ fertilized cropped soils with high nitrification potential (NP), the majority of the recovery of NP (RNP) activity after inhibition with acetylene was due to $\mathrm{AOB}$, and that in pasture and grassland soils with lower NP activity, RNP was due primarily to AOA or to a mixture of $\mathrm{AOA}$ and $\mathrm{AOB}$. A subsequent study has shown that the factors controling the relative contributions are complex with cropping treatment, soil conditions, and $\mathrm{NH}_{4}{ }^{+}$availability influencing their relative contributions in the field (Taylor et al., 2012). Using soils from our same site, investigations into the kinetics of ammonia oxidation found $\mathrm{K}_{\mathrm{m}}$ values similar to other soils (0.02 mM) but less than for pure cultures of AOB (Koper et al., 2010). Based on the above mentioned studies, AOB will likely be relatively more important players in the AS and LW treated plots in our system, with AOA being functionally more important in the control and DC treated plots. However, since archived samples are not appropriate for testing this hypothesis, additional experimentation requires sampling soil from new experimental plots in future investigations.

\section{THE USE OF THE VARIABLE SIZE amo INTERGENIC REGION TO PROFILE AOB}

Visible products of the amo intergenic region from soil DNA extracts (Figure 3) were obtained through semi-nested PCR reactions. Several primer sets were assessed through use with pure cultures of AOB, soil DNA and in silico and the use of amoC305/amoA310 resulted in the most reproducible banding patterns. The predicted and observed sizes of the amplicons of amoC305F/amoA310R from some pure culture AOB strains are shown in Table 2. DNA extracts from soils that received the AS, DC, and LW treatments were first amplified with amoC305F/amoA302R primer sets and subsequently semi-nested with amoC305F/amoA310R. PCR amplification of the genomic DNA of the pure culture strains indicated that amoC305F/amoA302R gave a single band amplicon for all the

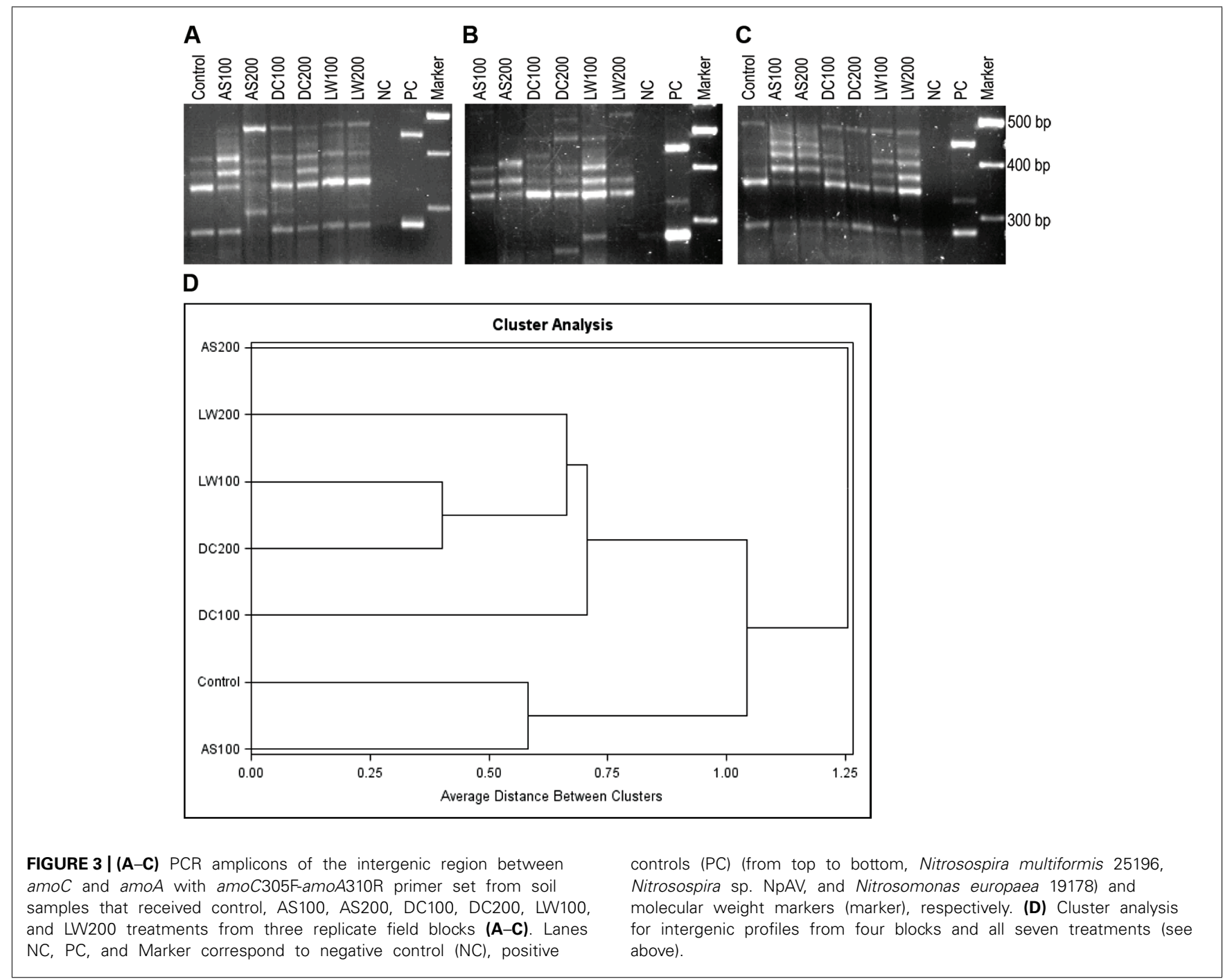


Table 2 | Copy number of amo operon and size of the intergenic regions between amoC and amoA of various pure culture $A O B$ strains. Amplicon length predicted from sequence.

\begin{tabular}{llll}
\hline Strain & Copy number & $\begin{array}{l}\text { a amoC-amoA } \\
\text { intergenic region (bp) }\end{array}$ & 305F-310R amplicon (bp) \\
\hline Nitrosospira sp. NpAV & 3 & 223 & 331 \\
N. briensis C-128 & 3 & 263 & 371 \\
Nitrosospira sp. 39-19 & 3 & 445 & 553 \\
N. tenuis NV-12 & 2 & 427 & 435 \\
Nitrosospira multiformis 25196 & 3 & 336 & 446 \\
Nitrosospira multiformis 24C & 3 & 261 & 369 \\
Nitrosomonas cryotolerans & 3 & 195 & 303 \\
Nitrosomonas europaea 19178 & 2 & 163 & 277 \\
N. eutropha C-91 & 2 & 173 & 287 \\
Nitrosomonas sp. AL212 & 3 & 174 & 282 \\
\hline
\end{tabular}

a Norton etal. (2002, 2008), Suwa etal. (2011).

pure cultures as predicted. Although direct amoC305F/amoA310R amplification with genomic DNA gave multiple bands for some of the strains, we did not observe this in semi-nested PCR (data not shown). The profiles of the amoC305F/amoA310R amplicons (Figure 3) show differences in AOB community composition between the different treatments. The amoC305/amoA310 gave visible bands (5-10 total) for all the treatments from all of the field block replicates, three of which are shown in Figure 3. The band patterns of each treatment from the field block replicates were not exactly identical indicating the inherent variability among the replicates.

Comparison of the band pattern of the control with the rest of the treatments indicates that the control had the lowest number of visible bands (Figure 3). As indicated in Table 2 and in additional test gels all of the Nitrosospira pure culture strains had intergenic amplicons of amoC305/amoA310 larger than 300 bp whereas the Nitrosomonas strains had less than $300 \mathrm{bp}$ intergenic amplicons with the exception of the marine strain Nitrosomonas cryotolerans. We observed bands indicating the presence of Nitrosomonas- and Nitrosospira-like strains from all treatments as verified by hybridization analysis (data not shown). Cluster analysis (Figure 3D) suggests three clusters: (1) control and AS100, (2) LW100, DC200, LW200, DC100, and (3) AS200. The AS200 community is the most distinct likely due to the highest amounts of ammonium addition. Currently methods are in development to simplify quantification and accurate sizing of the band patterns in intergenic profiles by using fluorescently labeled primers and genotyping methods. Similar methods may be developed for the AOA with attention to the different arrangement of the amo operon in these prokaryotes (Tavormina et al., 2011).

\section{CLONE LIBRARIES OF amoA GENES}

The nucleic acid based comparison of the clone sequences and selected pure culture AOB and AOA strains is shown in Figures 4 and 5. The corresponding amino acid based phylogenetic trees (not shown) were also constructed resulting in similar topology but with differences in branch lengths separating two sequences due to the occurrences of neutral mutations in amino acids (Rotthauwe et al., 1997). The superiority of nucleotide sequence over amino acids for analyzing phylogenetic relationship between closely related strains of bacteria has been previously noted (Yamamoto and Harayama, 1996; Rotthauwe et al., 1997).

Clone libraries of partial amoA sequences from soils that received the AS200, DC200, and LW200 indicated that Nitrosospira-like strains were the dominant AOB (\# of unique sequences for AS, DC and LW - 18, 15, \& 17). None of the sequences suggested previously undiscovered AOB species (Purkhold et al., 2000). The dominance of Nitrosospira-like strains in these soils is not surprising as it has been widely reported before in soils under different management systems (Stephen et al., 1996; Bruns etal., 1999; He etal., 2007; Boyle-Yarwood et al., 2008; Taylor et al., 2012). Nitrosomonas-like sequences were detected only from soils that received the LW200 treatment and constituted around $12 \%$ of the sequenced clones. This is consistent with the work by Oved et al. (2001) where wastewater effluent treated soils had both Nitrosospira and Nitrosomonas like sequences whereas only Nitrosospira like sequences were detected in soils that received inorganic fertilizer treatment. Enrichments from the LW have been shown to contain amoA genes related to Nitrosomonas spp. All clone sequences obtained from soils that received the AS200 and DC200 treatments were Nitrosospira-like. This might not necessarily mean that Nitrosomonas-like sequences did not exist in these soils. Mendum and Hirsch (2002) were able to detect only Nitrosospira-like sequences using PCR based techniques that targeted the 16S rRNA genes in soils that received ammonium nitrate and mixture of farmyard manure and ammonium nitrate for several years. They mentioned that Nitrosomonas species were isolated from same soil samples with enrichment cultures and that the PCR based technique was not able to detect Nitrosomonas likely due to their low relative abundance. Similarly, Phillips et al. (2000a) were not able to detect Nitrosomonas-like bands in DGGE analysis of 16S rRNA genes extracted directly from fertilized soils whereas these bands were detected from soil samples that were incubated in a medium containing 


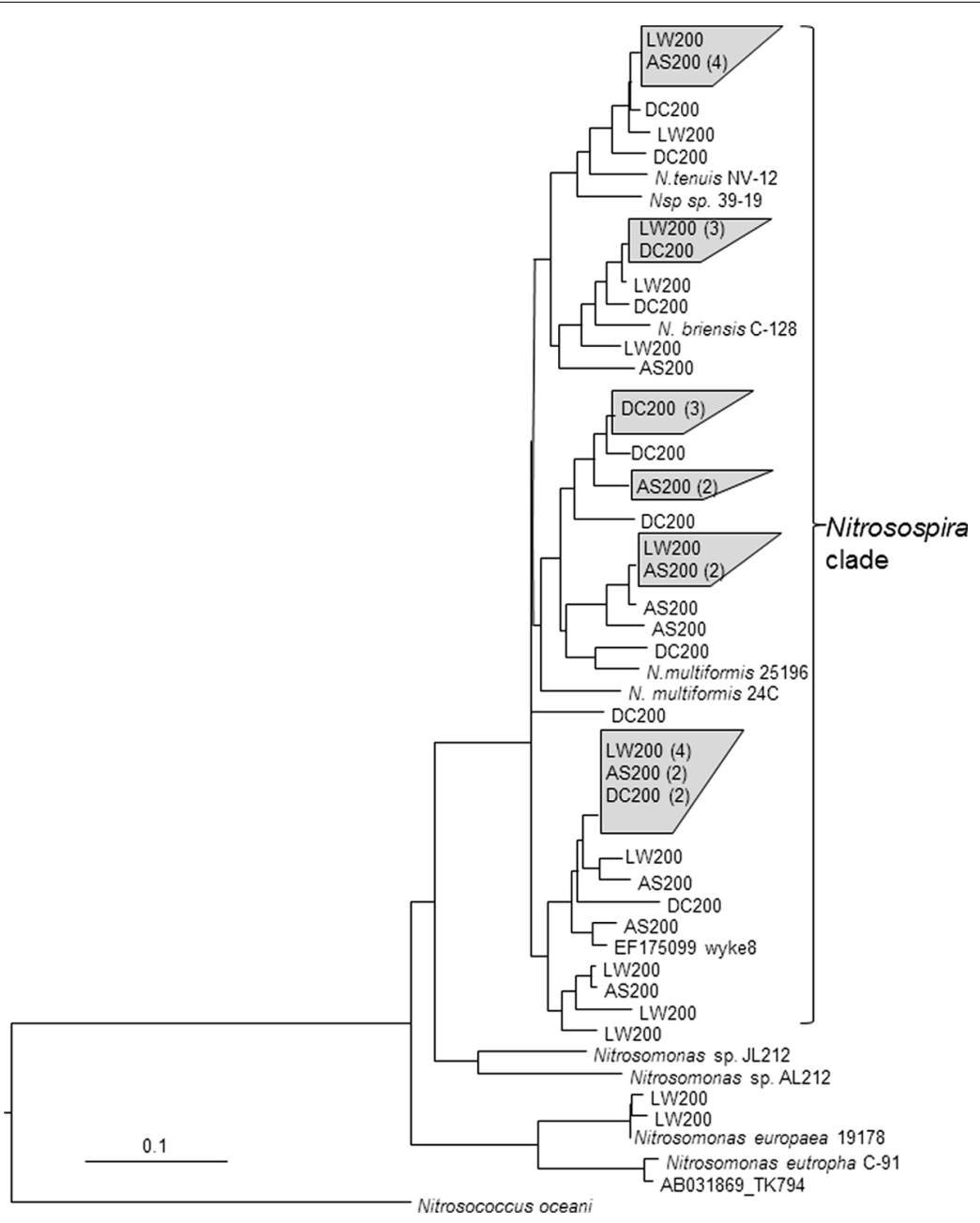

FIGURE 4 | Analysis of clone library sequences for bacterial amoA gene (534 bp). Neighbor joining tree for bacterial partial amoA sequences from soils from the various treatments (see Figure 1) and reference sequences from GenBank. Scale represents number of changes per $100 \mathrm{bp}$. Clone sequences from this study are in bold and designated with the treatment (see Figure 1) and are followed with the number of clones with sequences with $>99 \%$ identity.
$1000 \mu \mathrm{g} \mathrm{NH}_{4}{ }^{+}-\mathrm{N} \mathrm{mL}{ }^{-1}$ for MPN counts. Inherent biases associated with molecular techniques that might shift the relative proportion of the different $a m o A$ sequences may also explain nondetection of certain group of AOB from environmental samples (Rotthauwe et al., 1997).

The results from the clone libraries were similar with the results obtained by targeting the variable size intergenic amo region in that both techniques indicated differential impacts of the treatments on the $\mathrm{AOB}$ community composition. The difference is that profiling based on the intergenic region indicated the presence of both Nitrosospira and Nitrosomonas like populations in all the treatments whereas only Nitrosospira like populations were detected with the clone library method except in LW200 treatments. It seems that profiling AOB community composition by targeting the intergenic region could be useful in getting a quick snapshot of the community in a manner that is more inclusive because of nesting during PCR, which could pick up the less abundant Nitrosomonas like populations. This method can also be used to further identify the population type by excising, purifying and sequencing the DNA in the different bands.

The differential response of the AOB community to the treatments is reasonable considering the different forms of $\mathrm{N}$ and $\mathrm{C}$ inputs associated with each treatment. Peacock et al. (2001) noted that application of dairy manure over a 5-year period resulted in significant increase in $\mathrm{C}, \mathrm{N}$ and soil microbial biomass, as well as changes in microbial community structure. They indicated that those practices that enhance soil carbon and provide slowly mineralizable nutrients might result in larger and potentially more robust microbial community. The above statement is relevant to the DC treatment, which might have a long-term effect on the AO community due to its impact on the organic $\mathrm{C}$ and $\mathrm{N}$ pools of the soil. The DC and LW treatments might also change the AOB community composition by directly inoculating the soil with new AO strains. Strains inoculated this way are often not the dominant populations in the soil (Innerebner 
et al., 2006). The effect of inorganic $\mathrm{N}$ fertilizers might mainly be to increase the size of the AOB population without a corresponding change in composition (Phillips et al., 2000a). However, there have been studies that reported changes in $\mathrm{AOB}$ community composition in response to inorganic $\mathrm{N}$ fertilizers (He et al., 2007; Glaser et al., 2010).

The AOA clone libraries were not significantly different between treatments with all dominated by a group of closely (>97\% identity) related sequences that group with the 1.1B Nitrososphaera clade associated with the soil fosmid 54d9 (Schleper and Nicol, 2010; Schleper, 2012; Figure 5). Clone AOA 62 represents 34 sequences $>99 \%$ identical and clone AOA 88 represents 38 sequences $>96 \%$ identical to that from soil fosmid $54 \mathrm{~d} 9$ (Treusch et al., 2005; Schleper, 2012; Figure 5). This group represents more than $89 \%$ of all clones from all soil treatments. There were several other clones representing minor components of the community all associated with Nitrososphaera clusters ( $>85 \%$ identity) previously found. These AOA lineages are commonly found in agricultural soils worldwide (Pester et al., 2012; Zhalnina et al., 2013). The low richness of the archaeal amo $A$ genes recovered is typical of observations that consider soils sampled at a single location (Alves et al., 2013). Their conclusion that dominant phylotypes showed local specificity is supported by our results.
In summary, gene counts for $\mathrm{AOB}$ were higher in soils from the AS200, AS100, and LW200 treatments $\left(2.5 \times 10^{7}, 2.5 \times 10^{7}\right.$, and $2.1 \times 10^{7}$ copies $\mathrm{g}^{-1}$ soil, respectively) than in the control $\left(8.1 \times 10^{6}\right.$ copies $\left.\mathrm{g}^{-1}\right)$ while the abundance of AOA was not significantly affected by treatment $\left(3.8 \times 10^{7}\right.$ copies $\mathrm{g}^{-1}$ soil, average). The ratio of $\mathrm{AOA} / \mathrm{AOB}$ was higher in the control and compost treated soils, both treatments have the majority of their ammonium supplied through mineralization of organic nitrogen. PCR amplification of the intergenic region between amoC and amoA was shown to be a potentially useful method of profiling changes in $\mathrm{AOB}$ community composition but the analogous method for AOA needs further development for the method to be generally useful. Clone libraries of partial amoA sequences indicated AOB related to Nitrosospira multiformis and AOA related to an uncultured Nitrososphaera soil fosmid (54d9) were prevalent. Ongoing investigations will address how AO community diversity and abundance is related to in situ ammonia oxidation activity.

\section{ACKNOWLEDGMENTS}

This work was supported by grants from the USDA NRICGP (\#9600839 and \#9935107-7808), NIFA Award 2011-67019-30178, the Vice President for Research at Utah State University, Utah Agricultural Experiment Station, Utah State University and approved

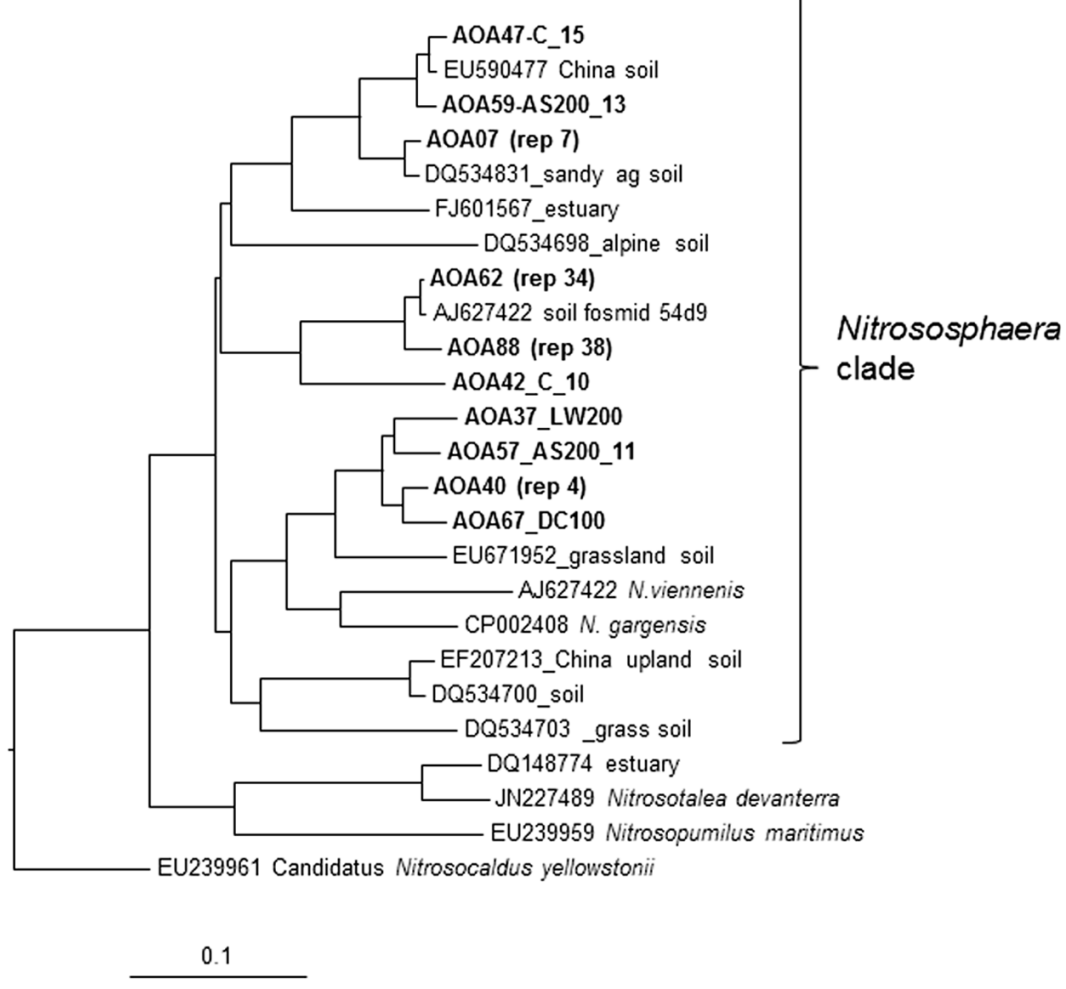

FIGURE 5 | Analysis of clone library sequences for archaeal amoA gene (570 bp). Neighbor joining tree for archaeal partial amoA sequences from soil samples that received ammonium sulfate (AS) dairy waste compost (DC) and liquid dairy waste (LW) at 100 and $200 \mathrm{~kg}$ available $\mathrm{N} \mathrm{ha}^{-1}$ annually for 6 years. Scale represents number of changes per $100 \mathrm{bp}$. Sequences from this study are shown in bold followed by the treatment designation and number of clone sequences (>97\% identical) that they represent (rep\#). Clone AOA 62 represents 34 sequences $>99 \%$ identical and clone AOA 88 represents 38 sequences $>97 \%$ identical to the amoA gene sequence from soil fosmid $54 d 9$. 
as journal paper 8559. Appreciation to Seth Thacker and Rita Nelson for laboratory and field assistance.

\section{REFERENCES}

Altschul, S. F., Madden, T. L., Schaffer, A. A., Zhang, J. H., Zhang, Z., Miller, W., et al. (1997). Gapped BLAST and PSI-BLAST: a new generation of protein database search programs. Nucleic Acids Res. 25, 3389-3402. doi: 10.1093/nar/25.17.3389

Alves, R. J. E., Wanek, W., Zappe, A., Richter, A., Svenning, M. M., Schleper, C., et al. (2013). Nitrification rates in Arctic soils are associated with functionally distinct populations of ammonia-oxidizing archaea. ISME J. 7, 1620-1631. doi: 10.1038/ismej.2013.35

Benson, D., Karsch-Mizrachi, I., Lipman, D., Ostell, J., and Wheeler, D. (2008). GenBank. Nucleic Acids Res. 36, D25-D30. doi: 10.1093/nar/gkm929

Boyle-Yarwood, S. A., Bottomley, P. J., and Myrold, D. D. (2008). Community composition of ammonia-oxidizing bacteria and archaea in soils under stands of red alder and Douglas fir in Oregon. Environ. Microbiol. 10, 2956-2965. doi: 10.1111/j.1462-2920.2008.01600.x

Bruns, M. A., Stephen, J. R., Kowalchuk, G. A., Prosser, J. I., and Paul, E. A. (1999). Comparative diversity of ammonia oxidizer 16S rRNA gene sequences in native, tilled, and successional soils. Appl. Environ. Microbiol. 65, 2994-3000.

Chain, P. S. G., Lamerdin, J., Larimer, F., Regala, W., Lao, V., Land, M., et al. (2003). Complete genome sequence of the ammonia-oxidizing bacterium and obligate chemolithoautotroph Nitrosomonas europaea. J. Bacteriol. 185, 2759-2773. doi: 10.1128/JB.185.9.2759-2773.2003

Di, H. J., Cameron, K. C., Shen, J. P., Winefield, C. S., O'callaghan, M., Bowatte, S., et al. (2010). Ammonia-oxidizing bacteria and archaea grow under contrasting soil nitrogen conditions. FEMS Microbiol. Ecol. 72, 386-394. doi: 10.1111/j.15746941.2010.00861.x

Engels, W. R. (1993). Contributing software to the internet-the amplify program. Trends Biochem. Sci. 18, 448-450. doi: 10.1016/0968-0004(93)90148-G

Glaser, K., Hackl, E., Inselsbacher, E., Strauss, J., Wanek, W., ZechmeisterBoltenstern, S., et al. (2010). Dynamics of ammonia-oxidizing communities in barley-planted bulk soil and rhizosphere following nitrate and ammonium fertilizer amendment. FEMS Microbiol. Ecol. 74, 575-591. doi: 10.1111/j.15746941.2010.00970.x

Gubry-Rangin, C., Nicol, G. W., and Prosser, J. I. (2010). Archaea rather than bacteria control nitrification in two agricultural acidic soils. FEMS Microbiol. Ecol. 74, 566-574. doi: 10.1111/j.1574-6941.2010.00971.x

Habteselassie, M. Y., Miller, B. E., Thacker, S. G., Stark, J. M., and Norton, J. M. (2006a). Soil nitrogen and nutrient dynamics after repeated application of treated dairy-waste. Soil Sci. Soc. Am. J. 70, 1328-1337. doi: 10.2136/sssaj2005.0189

Habteselassie, M. Y., Stark, J. M., Miller, B. E., Thacker, S. G., and Norton, J. M. (2006b). Gross nitrogen transformations in an agricultural soil after repeated dairy-waste application. Soil Sci. Soc. Am. J. 70, 1338-1348. doi: 10.2136/sssaj2005.0190

He, J., Shen, J., Zhang, L., Zhu, Y., Zheng, Y., Xu, M., et al. (2007). Quantitative analyses of the abundance and composition of ammonia-oxidizing bacteria and ammonia-oxidizing archaea of a Chinese upland red soil under long-term fertilization practices. Environ. Microbiol. 9, 2364-2374. doi: 10.1111/j.14622920.2007.01358.x

Hofferle, S., Nicol, G. W., Pal, L., Hacin, J., Prosser, J. I., and Mandic-Mulec, I. (2010). Ammonium supply rate influences archaeal and bacterial ammonia oxidizers in a wetland soil vertical profile. FEMS Microbiol. Ecol. 74, 302-315. doi: 10.1111/j.1574-6941.2010.00961.x

Holmes, A. J., Costello, A., Lidstrom, M. E., and Murrell, J. C. (1995). Evidence that particulate methane monooxygenase and ammonia monooxygenase may be evolutionarily related. FEMS Microbiol. Lett. 132, 203-208. doi: 10.1111/j.15746968.1995.tb07834.x

Innerebner, G., Knapp, B., Vasara, T., Romantschuk, M., and Insam, H. (2006). Traceability of ammonia-oxidizing bacteria in compost-treated soils. Soil Biol. Biochem. 38, 1092-1100. doi: 10.1016/j.soilbio.2005.09.008

Jia, Z. J., and Conrad, R. (2009). Bacteria rather than Archaea dominate microbial ammonia oxidation in an agricultural soil. Environ. Microbiol. 11, 1658-1671. doi: 10.1111/j.1462-2920.2009.01891.x

Junier, P., Molina, V., Dorador, C., Hadas, O., Kim, O. S., Junier, T., et al. (2010). Phylogenetic and functional marker genes to study ammonia-oxidizing microorganisms (AOM) in the environment. Appl. Microbiol. Biotechnol. 85, 425-440. doi: $10.1007 /$ s00253-009-2228-9
Koper, T. E., Habteselassie, M. Y., Stark, J. M., and Norton, J. M. (2010). Nitrification exhibits Haldane kinetics in an agricultural soil treated with ammonium sulfate or dairy waste compost. FEMS Microbiol. Ecol. 74, 316-322. doi: 10.1111/j.15746941.2010.00960.x

Korsaeth, A., Molstad, L., and Bakken, L. R. (2001). Modelling the competition for nitrogen between plants and microflora as a function of soil heterogeneity. Soil Biol. Biochem. 33, 215-226. doi: 10.1016/S0038-0717(00)00132-2

Kowalchuk, G. A., and Stephen, J. R. (2001). Ammonia-oxidizing bacteria: A model for molecular microbial ecology. Annu. Rev. Microbiol. 55, 485-529. doi: 10.1146/annurev.micro.55.1.485

Leininger, S., Urich, T., Schloter, M., Schwark, L., Qi, J., Nicol, G. W., et al. (2006). Archaea predominate among ammonia-oxidizing prokaryotes in soils. Nature 442, 806-809. doi: 10.1038/nature04983

Ludwig, W., Strunk, O., Westram, R., Richter, L., Meier, H., Yadhukumar., et al. (2004). ARB: a software environment for sequence data. Nucleic Acids Res. 32, 1363-1371. doi: 10.1093/nar/gkh293

McTavish, H., Fuchs, J. A., and Hooper, A. B. (1993). Sequence of the gene coding for ammonia monooxygenase in Nitrosomonas europaea. J. Bacteriol. 175, 2436-2444.

Mendum, T. A., and Hirsch, P. R. (2002). Changes in the population structure of beta-group autotrophic ammonia oxidising bacteria in arable soils in response to agricultural practice. Soil Biol. Biochem. 34, 1479-1485. doi: 10.1016/S00380717(02)00092-5

Norton, J. M. (2008). "Nitrification in Agricultural Soils," in Nitrogen in Agricultural Systems, eds J. S. Schepers and W. R. Raun (Madison, WI: American Society of Agronomy, Inc.), 173-199.

Norton, J. M., Alzerreca, J. J., Suwa, Y., and Klotz, M. G. (2002). Diversity of ammonia monooxygenase operon in autotrophic ammonia-oxidizing bacteria. Arch. Microbiol. 177, 139-149. doi: 10.1007/s00203-001-0369-z

Norton, J. M., Klotz, M. G., Stein, L. Y., Arp, D. J., Bottomley, P. J., Chain, P. S. G., et al. (2008). Complete genome sequence of Nitrosospira multiformis, an ammoniaoxidizing bacterium from the soil environment. Appl. Environ. Microbiol. 74, 3559-3572. doi: 10.1128/AEM.02722-07

Offre, P., Prosser, J. I., and Nicol, G. W. (2009). Growth of ammonia-oxidizing archaea in soil microcosms is inhibited by acetylene. FEMS Microbiol. Ecol. 70, 99-108. doi: 10.1111/j.1574-6941.2009.00725.x

Okano, Y., Hristova, K. R., Leutenegger, C. M., Jackson, L. E., Denison, R. F., Gebreyesus, B., et al. (2004). Application of real-time PCR to study effects of ammonium on population size of ammonia-oxidizing bacteria in soil. Appl. Environ. Microbiol. 70, 1008-1016. doi: 10.1128/AEM.70.2.1008-1016. 2004

Oved, T., Shaviv, A., Goldrath, T., Mandelbaum, R. T., and Minz, D. (2001). Influence of effluent irrigation on community composition and function of ammonia-oxidizing bacteria in soil. Appl. Environ. Microbiol. 67, 3426-3433. doi: 10.1128/AEM.67.8.3426-3433.2001

Peacock, A. D., Mullen, M. D., Ringelberg, D. B., Tyler, D. D., Hedrick, D. B., Gale, P. M., et al. (2001). Soil microbial community responses to dairy manure or ammonium nitrate applications. Soil Biol. Biochem. 33, 1011-1019. doi: 10.1016/S0038-0717(01)00004-9

Pester, M., Rattei, T., Flechl, S., Groengroeft, A., Richter, A., Overmann, J., et al. (2012). amoA-based consensus phylogeny of ammonia-oxidizing archaea and deep sequencing of $a m o A$ genes from soils of four different geographic regions. Environ. Microbiol. 14, 525-539. doi: 10.1111/j.1462-2920.2011. 02666.x

Phillips, C. J., Harris, D., Dollhopf, S. L., Gross, K. L., Prosser, J. I., and Paul, E. A. (2000a). Effects of agronomic treatments on structure and function of ammonia-oxidizing communities. Appl. Environ. Microbiol. 66, 5410-5418. doi: 10.1128/AEM.66.12.5410-5418.2000

Phillips, C. J., Paul, E. A., and Prosser, J. I. (2000b). Quantitative analysis of ammonia oxidising bacteria using competitive PCR. FEMS Microbiol. Ecol.32, 167-175. doi: 10.1111/j.1574-6941.2000.tb00710.x

Prosser, J. I., and Embley, T. M. (2002). Cultivation-based and molecular approaches to characterisation of terrestrial and aquatic nitrifiers. Antonie Van Leeuwenhoek 81, 165-179. doi: 10.1023/A:1020598114104

Purkhold, U., Pommerening-Roser, A., Juretschko, S., Schmid, M. C., Koops, H. P., and Wagner, M. (2000). Phylogeny of all recognized species of ammonia oxidizers based on comparative 16S rRNA and amoA sequence analysis: Implications for molecular diversity surveys. Appl. Environ. Microbiol. 66, 5368-5382. doi: 10.1128/AEM.66.12.5368-5382.2000 
Rotthauwe, J. H., Witzel, K. P., and Liesack, W. (1997). The ammonia monooxygenase structural gene $a m o A$ as a functional marker: Molecular fine-scale analysis of natural ammonia-oxidizing populations. Appl. Environ. Microbiol. $63,4704-4712$.

Schleper, C. (2010). Ammonia oxidation: different niches for bacteria and archaea? ISME J. 4, 1092-1094. doi: 10.1038/ismej.2010.111

Schleper, C. (2012). Metagenomic analysis of ammonia oxidizing archaea affiliated with the soil group. Front. Microbiol. 3:208. doi: 10.3389/fmicb.2012.00208

Schleper, C., and Nicol, G. W. (2010). "Ammonia-oxidising archaea - physiology, ecology and evolution," in Advances in Microbial Physiology, Vol. 57, ed. R. K. Poole (London: Academic Press Ltd-Elsevier Science Ltd), 1-41.

Shi, W., Miller, B. E., Stark, J. M., and Norton, J. M. (2004). Microbial nitrogen transformations in response to treated dairy waste in agricultural soils. Soil Sci. Soc. Am. J. 68, 1867-1874. doi: 10.2136/sssaj2004.1867

Stephen, J. R., Mccaig, A. E., Smith, Z., Prosser, J. I., and Embley, T. M. (1996). Molecular diversity of soil and marine 16S rRNA gene sequences related to beta-subgroup ammonia-oxidizing bacteria. Appl. Environ. Microbiol. 62, 4147-4154.

Suwa, Y., Norton, J. M., Bollmann, A., Klotz, M. G., Stein, L. Y., Laanbroek, H. J., et al. (2011). Genome sequence of Nitrosomonas sp. strain AL212, an ammoniaoxidizing bacterium sensitive to high levels of ammonia. J. Bacteriol. 193, 50475048. doi: 10.1128/JB.06107-11

Tavormina, P. L., Orphan, V. J., Kalyuzhnaya, M. G., Jetten, M. S. M., and Klotz, M. G. (2011). A novel family of functional operons encoding methane/ammonia monooxygenase-related proteins in gammaproteobacterial methanotrophs. Environ. Microbiol. Rep. 3, 91-100. doi: 10.1111/j.1758-2229. 2010.00192.x

Taylor, A. E., Zeglin, L. H., Dooley, S., Myrold, D. D., and Bottomley, P. J. (2010). Evidence for different contributions of archaea and bacteria to the ammoniaoxidizing potential of diverse oregon soils. Appl. Environ. Microbiol. 76, 76917698. doi: 10.1128/AEM.01324-10

Taylor, A. E., Zeglin, L. H., Wanzek, T. A., Myrold, D. D., and Bottomley, P. J. (2012). Dynamics of ammonia-oxidizing archaea and bacteria populations and contributions to soil nitrification potentials. ISME J. 6, 2024-2032. doi: 10.1038/ismej.2012.51

Treusch, A. H., Leininger, S., Kletzin, A., Schuster, S. C., Klenk, H. P., and Schleper, C. (2005). Novel genes for nitrite reductase and Amo-related proteins indicate a role of uncultivated mesophilic crenarchaeota in nitrogen cycling. Environ. Microbiol. 7, 1985-1995. doi: 10.1111/j.1462-2920.2005.00906.x

Verhamme, D. T., Prosser, J. I., and Nicol, G. W. (2011). Ammonia concentration determines differential growth of ammonia-oxidising archaea and bacteria in soil microcosms. ISME J. 5, 1067-1071. doi: 10.1038/ismej. 2010.191
Webster, G., Embley, T. M., Freitag, T. E., Smith, Z., and Prosser, J. I. (2005) Links between ammonia oxidizer species composition, functional diversity and nitrification kinetics in grassland soils. Environ. Microbiol. 7, 676-684. doi: 10.1111/j.1462-2920.2005.00740.x

Wessen, E., Nyberg, K., Jansson, J. K., and Hallin, S. (2010). Responses of bacterial and archaeal ammonia oxidizers to soil organic and fertilizer amendments under long-term management. Appl. Soil Ecol. 45, 193-200. doi: 10.1016/j.apsoil.2010.04.003

Xia, W. W., Zhang, C. X., Zeng, X. W., Feng, Y. Z., Weng, J. H., Lin, X. G., et al. (2011). Autotrophic growth of nitrifying community in an agricultural soil. ISME J. 5, 1226-1236. doi: 10.1038/ismej.2011.5

Yamamoto, S., and Harayama, S. (1996). Phylogenetic analysis of Acinetobacter strains based on the nucleotide sequences of gyrB genes and on the amino acid sequences of their products. Int. J. Syst. Bacteriol. 46, 506-511. doi: 10.1099/00207713-46-2-506

Zeglin, L. H., Taylor, A. E., Myrold, D. D., and Bottomley, P. J. (2011). Bacterial and archaeal amoA gene distribution covaries with soil nitrification properties across a range of land uses. Environ. Microbiol. Rep. 3, 717-726. doi: 10.1111/j.17582229.2011.00290.x

Zhalnina, K., De Quadros, P. D., Gano, K. A., Davis-Richardson, A., Fagen, J. R., Brown, C. T., et al. (2013). Ca. Nitrososphaera and Bradyrhizobium are inversely correlated and related to agricultural practices in long-term field experiments. Front. Microbiol. 4:104. doi: 10.3389/fmicb.2013.00104

Zhou, J. Z., Bruns, M. A., and Tiedje, J. M. (1996). DNA recovery from soils of diverse composition. Appl. Environ. Microbiol. 62, 316-322.

Conflict of Interest Statement: The authors declare that the research was conducted in the absence of any commercial or financial relationships that could be construed as a potential conflict of interest.

Received: 07 June 2013; accepted: 15 October 2013; published online: 06 November 2013.

Citation: Habteselassie MY, Xu L and Norton JM (2013) Ammonia-oxidizer communities in an agricultural soil treated with contrasting nitrogen sources. Front. Microbiol. 4:326. doi: 10.3389/fmicb.2013.00326

This article was submitted to Terrestrial Microbiology, a section of the journal Frontiers in Microbiology.

Copyright (c) 2013 Habteselassie, Xu and Norton. This is an open-access article distributed under the terms of the Creative Commons Attribution License (CC BY). The use, distribution or reproduction in other forums is permitted, provided the original author(s) or licensor are credited and that the original publication in this journal is cited, in accordance with accepted academic practice. No use, distribution or reproduction is permitted which does not comply with these terms. 